\title{
Determinants of Police and Community Cooperation in Policing: A Case of Imenti North Sub - County, Meru County (Kenya)
}

\author{
Patrick Mugambi \\ Wokabi Mwangi \\ Panuel Mwaeke
}

\begin{abstract}
This study sought to examine the determinants of police and community cooperation in policing Imenti North Sub - County within Meru County Jurisdiction. The focus was on five locations of Imenti North Sub - County namely; Municipality, Ntima East, Ntima West, Nyaki East and Nyaki West. The study used interview schedule method to collect data from 183 respondents who included household heads, Chiefs, Community Policing Committee members and police officers. Data was analyzed with the aid of Statistical Package for Social Sciences (SPSS) version 20. Lack of trust and confidence in the police were found to be the key hindrances to community - police co-operation in Imenti North Sub-County. This study recommends that police agencies should build partnerships with the citizens in order to increase their ability to maintain law and order and therefore solve crimes.
\end{abstract}

Keywords: Community, Determinants, Disparate targeting, Policing, Public

\section{INTRODUCTION}

Determinant of police and community cooperation in policing is dependent upon the level of trust each have for the other. The police as one of the criminal justice systems must maintain high public trust if the system is to perform its mission successfully. Consequently, public cooperation can enhance police effectiveness and the legitimacy of their actions (Sunshine and Tyler, 2003). Goldstein, (1990) posit that police - public cooperation in policing determines the effectiveness and efficiency in terms of crime control, reducing fear of crime, improving quality of life for the local residents and strengthening police legitimacy and public confidence. On the other hand, deficit of cooperation between the police and the public can prove disastrous to the efforts of crime prevention in any given country

Globally, there is evidence that police - public cooperation has increased effectiveness and efficiency in crime control and improvement of life for the local residents. According to Wilson, (2009), police in the UK enjoy a relatively high level of public trust thus serious crime rates have gone down. In contrast, the Sub-Saharan African region has experienced increased police - citizen conflict leading to increased crime rates and instability. For instance, Marais, (1993) argue that the relationship between police agencies and significant sectors of South Africa's population is characterized by mistrust and even hostility. This has led to increased crime rates in poor urban neighborhoods yet the factors which have an effect on police-community cooperation culminating to decreased crime rates have received little attention in policing.

Meru county (Kenya) in general and Imenti North sub county in particular is not exception to increased crime rates which have been attributed to strained relationship between the police and the local community they serve. Therefore, this study is intended to evaluate the factors 
that shape the relationship between the public and the police with a view of drawing recommendations that will benefit Kenya's National Police Service (NPS), the community and national security policy makers in expediting their fight against crime.

\section{STATEMENT OF THE PROBLEM}

Security is a key pillar to socio-economic development and prosperity in every society. However, in Imenti North Sub - County, this has become elusive as insecurity characterized by armed robberies, house breaking, theft, murder, use of drugs and other serious crimes is on the increase. Whereas non-cooperation between the police and the community of Imenti North Sub - County is considered to be ccontributing to rise of crimes, no empirical studies have been carried on the determinants of police and community cooperation in policing the area. Therefore, this study sought to investigate the factors that hinder the relationship between the police and community with a view of improving cooperation for crime reduction and greater levels of personal safety and social order.

\section{SPECIFIC OBJECTIVES OF THE STUDY}

The specific objective of this study was to investigate the factors determining communitypolice cooperation in policing Imenti North Sub - County of Meru County, Kenya.

\section{METHODOLOGY}

This study used a descriptive survey design to investigate the determinants of police and community cooperation in policing Imenti North Sub - County. As Cresswell, (2008) asserts, descriptive survey design is ideal for gathering information about people's perception and attitude, opinions, habits and variety of social issues. It also allows details to be obtained from multiple sources of information and evidence to be verified through in-depth probing.

\section{DETERMINANTS OF COMMUNITY COOPERATION WITH THE POLICE}

\section{Trust}

Available literature on the determinants of police and community cooperation in policing indicates that public trust on the police institution can exist only when the police execute their duties with fairness, equity, professionalism, and firmness. Sunshine \& Tyler (2003) asserts that, trust is a factor that determine citizens' cooperation and support to the police. Consequently, Goldstein (1990) contends that trust is linked to the capacity of police to provide basic security to the citizens. However, this study points out that effective police work, good and confidential relationship are of primary importance for the community cooperation with the police for the purposes of earning legitimacy in the community.

\section{Confidence}

Confidence in police as an organization and institution capable of fighting crime determines public support and cooperation (Sunshine \& Tyler, 2003). Acknowledging the importance of public opinion toward the police ability to fight crime by using data from the World Values Surveys in 1995-1997, Cao \& Dai, (2006) found that about 59 percent of the Taiwanese citizens expressed confidence in their police. In another study, it was noted that confidence in the police was part of a broader attitudinal complex of larger legal and political systems. An empirical assessment of the public perceptions of the police in Mexico re-emphasized how little confidence people have in municipal, state, or federal police agencies (Brown et al, 2006). Almost 70 percent of the respondents reported that the state police agencies do an inadequate job when it comes to controlling crime, investigating burglaries, fraud, and murder, and in treating people fairly. 


\section{Community Politics}

According to Kenya National Commission on Human Rights, (2008), community politics in Kenya defines public cooperation and support to the police. The study pointed out that the Kenya Police Service has a long tradition of being a partisan instrument in the hands of the rulers since colonial times. This unholy nexus developed between police officers and unscrupulous politicians has led to partisan and politicized police which has often been used to intimidate adversaries and reward supporters. When the police uses its discretionary powers and enforces the law in a selective manner, as happens quite blatantly in many parts of Kenya (Imenti North Sub- County not excluded), it is no longer trusted by the people thus a factor determining community lack of support to the police. The registration of cases, their investigation and prosecution has increasingly become a matter of political expediency. Even arrests and searches by the police are often made to serve partisan ends thus eroding citizen's cooperation with the police.

\section{Media Influence}

The media has also surfaced as a major source of public scrutiny of the police. Private-owned news agencies tend to actively search for sensational news on the government and public figures to entice audience. Negative and sometimes exaggerated reports of police misconduct on televisions, newspapers and the Internet apparently serve such purpose fairly well. Being exposed to and believing in negative news about the police lower citizens' satisfaction leading to non-cooperation (Huang, 2012). This study points out that while the media is seen as an agent for channeling information to the masses, the public should be enabled to penetrate more information through various types of media including, newspapers, magazine, billboards, TV's news and programmes, radio, web, blogs, social media and SMS about important massages such as awareness of crime and criminal behavior as a crime prevention effort.

\section{Disparate Targeting}

The effect of the disparate targeting of particular ethnic, religious or social status group in the population in crime-control contexts has an impact on community perception of the police force. The unequal allocation of policing attention and sanctions along ethnic, religious or social status lines makes vulnerable members of the society to feel they are the target of unwarranted attention motivated by prejudice. As Rice \& Parkin (2010) assert, this harassment can be negatively reciprocated thus in turn undermines perceptions of fairness and legitimacy of the police amongst the population.

\section{Verbal Encounters}

According to Rønneberg, (2012), impact of verbal encounters is a factor that determines public cooperation and support to the police. The main part of ordinary police work consists of patrolling and answering calls meant to requests for information, advice and assistance, to reports about anything ranging from minor incidents to observations of accidents, suspicious events and committed offence. This means that most police officers are in a daily and direct contact with members of the public. This study points out that, during these encounters, especially if they take place by means of a telephone or face to face interview, language not only provides an important means to solve problems and exert social control but also helps to build relations as well as to inspire confidence and trust. In this way, the communication process between police and the public provides the basis for police legitimacy and consequently for successful police work since the police depend on the public for information, co-operation and support. During such verbal meetings, the spoken language will provide the link between the police officer and the citizen, and as such, either serve as a tool to build relations and inspire confidence, or on the other hand, create distance and possible distrust (Lurigio \& Skogan, 1994). 


\section{Public Trust}

\section{RESULTS}

The study sought to establish whether trust by members of the community affected their relationship with the police. The results are presented in Figure 1.

Figure 1: The Effect of Trust in Community-Police Cooperation

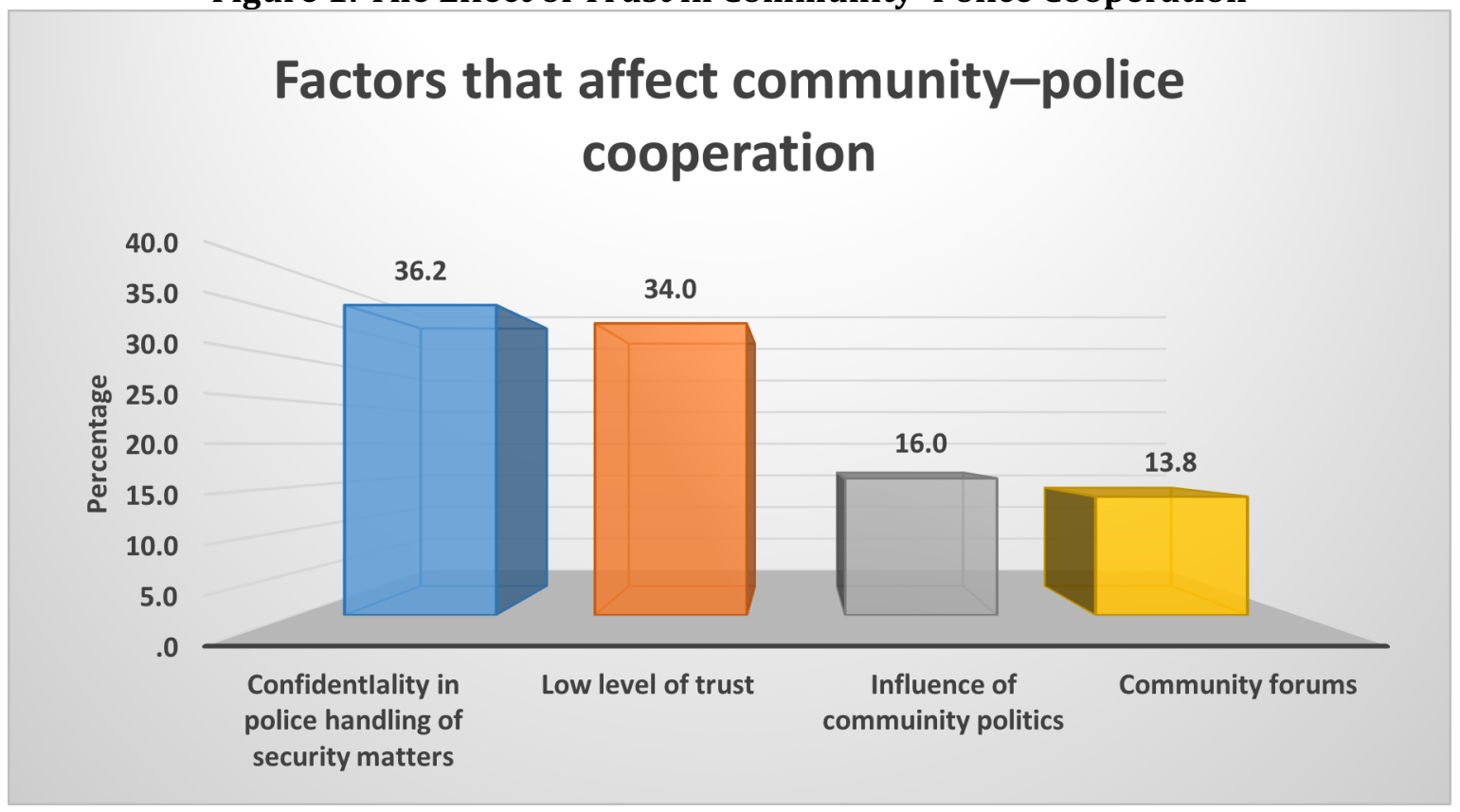

From figure 1, 36.2\% of the respondents reported that lack of confidentiality from the police especially when handling security matters was the main factor that affect community - police co-operation. In addition, 34\% indicated that community - police co-operation was hampered by the low level of trust the public has with the police

\section{Public Confidence in Police}

This study sought to measure the level of confidence the residents had in the police. The results are presented in the table 1 ;

Table 1: Level of Public Confidence in Police

\begin{tabular}{|l|c|c|}
\hline Category & Respondents & Percentage \\
\hline Very little & 52 & 55.3 \\
\hline Little & 23 & 24.5 \\
\hline Medium & 19 & 20.2 \\
\hline Total & $\mathbf{9 4}$ & $\mathbf{1 0 0}$ \\
\hline
\end{tabular}

Source: Field data (2017)

The results in the table reveals that citizen have low confidence with police. This is explained by inadequate job of the police in controlling and investigating crimes.

\section{Community Politics}

This study sought to determine whether community politics affected community co-operation with police. A statement 'police officers are likely to follow up with the victim's complaint because of political influence' was posed to the respondents and they were required to give levels of agreement with it. The results are presented in the table 2; 
Table 2: Likelihood of Police Following up with the Victim's Complaints Because of Political Influence

\begin{tabular}{|l|c|c|}
\hline & Frequency & Percent \\
\hline Strongly agree & 21 & 22.3 \\
\hline Agree & 33 & 35.1 \\
\hline Disagree & 11 & 11.7 \\
\hline Strongly disagree & 29 & 30.9 \\
\hline Total & 94 & 100.0 \\
\hline
\end{tabular}

Source: Field data (2017)

As illustrated in the table, the study established that most of the respondents $(57.4 \%)$ agreed that police are likely to follow up a victim's complaint/report against an offender when they are aware of the offender's political influence in the community. This implies that community politics play a major role in community-police cooperation.

\section{Media Influence on Community - Police Cooperation}

This study sought to determine whether media has influence on public scrutiny of the police, and were asked the extent to which their cooperation with the police is determined by what they hear or read. The results are indicated in table 3;

Table 3: Public Perception on the Extent of Media Influence on Community-Police Co-operation

\begin{tabular}{|l|c|c|}
\hline & Frequency & Percent \\
\hline Very high extent & 7 & 7.4 \\
\hline High extent & 38 & 40.4 \\
\hline Little extent & 22 & 23.4 \\
\hline Very little extent & 27 & 28.7 \\
\hline Total & $\mathbf{9 4}$ & $\mathbf{1 0 0 . 0}$ \\
\hline
\end{tabular}

Source: Field data (2017)

As illustrated in the table, almost half of the respondents (47.8\%) reported that their cooperation and perceptions towards the police largely. depends on what they hear or read in the media. However, $52.2 \%$ indicated that media has little influence on their perceptions and cooperation with the police. The results clearly illustrates that the media influences the residents of Imenti North Sub - County perception of cooperating with the police. Majority of them are exposed to and believe in negative news about the police and this lowers citizens' satisfaction thus leading to non-cooperation. Many residents claimed that police public picture determines community cooperation with police directly or indirectly.

Upon further inquiry in the in-depth interview, one of the respondent noted that, ".....Privateowned news agencies tend to actively search for sensational news on the government and public figures to entice audience...Sometimes exaggerated reports of police misconduct on televisions, newspapers and the Internet apparently serve such purpose fairly well."

\section{Disparate Targeting}

The study sought to investigate the influence of disparate targeting on community-police cooperation within Imenti North Sub-County. The results are presented in table 4; 
Mugambi, P., Mwangi, W., \& Mwaeke, P. (2018). Determinants of Police and Community Cooperation in Policing: A Case of Imenti North Sub County, Meru County (Kenya). Advances in Social Sciences Research Journal, 5(11) 531-538.

Table 4: How Disparate Targeting has Affected Community - Police Co-operation

\begin{tabular}{|c|c|c|}
\hline & Frequency & Percent \\
\hline Have led to low trust of police service & 22 & 23.4 \\
\hline Discriminatory in their quest to control crime & 20 & 21.3 \\
\hline Have led to mistrust of police officers & 20 & 21.3 \\
\hline Nepotism profiling/treatment & 19 & 20.2 \\
\hline Have led to fear of police & 13 & 13.8 \\
\hline Total & 94 & 100.0 \\
\hline
\end{tabular}

Source: Field data (2017)

The table depicts that, disparate targeting causes increase in level of mistrust of police (23.4\%) by the community and thus cooperation is inadequate. Further, disparate targeting has caused discrimination in the quest to control crime thus resulting to unequal allocation of policing attention and sanctions along ethnic, religious or social status lines in affected area. Moreover, it has led to fear of police by the public (13.8\%). One respondent stated that ".....as residents of this estate, we cannot cooperate with police in policing. Police officers perceive us as criminals and are discriminatory due to our social status. When a crime is committed in Meru town, they all run here in 'Shauri Yako estate' to make arrest because they think we are all criminals..."

\section{Verbal Encounters}

The study sought to investigate the influence of verbal encounters on community cooperation with police in Imenti North Sub County. The results are presented in the table 5;

Table 5: Ways Verbal Encounters by the Police have Affected Community-Police Cooperation in Policing

\begin{tabular}{|l|c|c|}
\hline & n & Percent \\
\hline Undermines the cooperation as they misinterpret any action taken by police & 33 & 35.1 \\
\hline Create distant relationship and possible distrust & 30 & 31.9 \\
\hline Insult the citizens and thus less cooperation & 18 & 19.1 \\
\hline Physical discomfort/lowers self esteem & 13 & 13.8 \\
\hline Total & $\mathbf{9 4}$ & $\mathbf{1 0 0 . 0}$ \\
\hline
\end{tabular}

Source: Field data (2017)

As illustrated in the table, the main effect of verbal encounters between the police and the community have undermined the cooperation as the public misconstrues any action taken by the police (35.1\%). They also create distant relationship and possible distrust between the police and the community (31.9\%). Moreover, the police insult the citizens and this leads to less cooperation from the public. When these verbal encounters occur, they lower the selfesteem of the members of the public and this affects their cooperation with the police. Upon further inquiry in the in-depth interview, one of the respondents noted that ".....police have poor communication skills... calling them to respond to crime offence take too long or even cannot respond prompting citizens to work alone. Their language break social control with ordinary citizens and we cannot see any reason of cooperating with them." This show that spoken language provides the link between police officers and the residents, and as such, either serve as a tool to build relations and inspire confidence or create distance and possible distrust.

\section{CONCLUSION}

In light of the research and observations made, this study has highlighted the issue of indifference among the police and its effect on the public willingness to cooperate with the police. Considering the context of police and community relations in Kenya, it might be more 
relevant at the beginning to focus on the program that can make the police more responsive to the public and vice versa. This is important when considered that the main challenge to effective cooperation relates to the attitudes of the community to the police. Thes results augured with Sunshine and Tyler, (2003), who stated that public cooperation can enhance police effectiveness and the legitimacy of their actions. Goldstein (1990) too posit that police public cooperation in policing determines the effectiveness and efficiency in terms of crime control, reducing fear of crime, improving quality of life for the local residents and strengthening police legitimacy and public confidence. The resident of Imenti North SubCounty indicated that public trust has a major impact on community-police cooperation in policing. Consequently, ineffective police work, has resulted to poor community cooperation with the police.

\section{RECOMMENDATIONS}

Based on the findings of the study, it is firstly recommended that, to change the citizens' view of police legitimacy, the government should function democratically and subordinate the police to the rule of law. This can be achieved by making the police accountable to an independent body that monitors their actions. Failure by the police to abide to the rule of law should attract sanctions not only to the individual officer but also to the police agency he or she represent.

Secondly, the Police administration should improve the police image in terms of professionalism, integrity and accountability. The National Police Service in Kenya should continuously inform the public about its mission and values and conduct their work in line with the principles of the rule of law, protection of human rights and democratic policing.

Thirdly, the government should strengthen the adoption of community policing as a style of policing through budgetary allocations to cater for community policing committee members and informers.

\section{References}

Brown, R., Benedict, W. \& Wilkinson, W. (2006). Public perceptions of the police in Mexico. An International Journal of Police Strategies and Management, 29, 158-175.

Cao, L., \& Dai, M. (2006). Confidence in the Police: Where does Taiwan Rank in the World?Asian Journal of Criminology, 1(1), 71-84.

Cresswell, W. (2012). Educational research: Planning, conducting, and evaluating quantitative and qualitative research. Upper Saddle River, NJ: Pearson Education

Goldstein, H. (1990). Problem oriented policing. New York: McGraw-Hill.

Huang, Y. (2012). The media, political party orientation, and attitudes toward the police. Taipei, Taiwan: National Taipei University.

Kenya National Commission on Human Rights (2008) Cry of Blood - Report on Extrajudicial Killings and Disappearances. Nairobi: KNCHR

Lurigio, A. \& Skogan, W. (1994). Winning the Hearts and Minds of Police Officers: An Assessment of Staff Perceptions of Community Policing in Chicago. Crime \& Delinquency, 40(3), 315-330.

Marais, E. (1993). The police - Community Relationship. In Glanz, L. (ed). Managing Crime in the New South Africa: Pretoria: HSRC Publishers.

Rice, K. and Parkin, W. (2010). New Avenues for Profiling Research: The Question of Muslim Americans. In S. K. Rice and M. D. White (eds), Race, Ethnicity and Policing. New York: New York University Press

Rønneberg, K. (2012). Public confidence in the police: The impact of verbal encounters. Open Journal of Modern Liguistics, 2(1), 1-7.

Sunshine, J., \& Tyler, R. (2003). The role of Procedural Justice and Legitimacy in Shaping Public Support for Policing. Law \& Society Review 37:513-48 
Mugambi, P., Mwangi, W., \& Mwaeke, P. (2018). Determinants of Police and Community Cooperation in Policing: A Case of Imenti North Sub County, Meru County (Kenya). Advances in Social Sciences Research Journal, 5(11) 531-538.

Wilson, J. (2009). Varieties of police behavior: The management of law and order in eight Communities. Cambridge, MA: Harvard University Press. 